\title{
Banana Peel Carbon Containing Functional Groups Applied to the Selective Adsorption of Au(III) from Waste Printed Circuit Boards
}

\author{
Huajun Zheng ${ }^{1,2 *}$, Limin Wang ${ }^{1}$ \\ ${ }^{1}$ Department of Applied Chemistry, Zhejiang University of Technology, Hangzhou, China; ${ }^{2}$ State Key Laboratory Breeding Base of \\ Green Chemistry Synthesis Technology, Zhejiang University of Technology, Hangzhou, China. \\ Email: ${ }^{*}$ zhenghj@zjut.edu.cn
}

Received December $28^{\text {th }}, 2012$; revised January $23^{\text {rd }}, 2013$; accepted February $3^{\text {rd }}, 2013$

Copyright (C) 2013 Huajun Zheng, Limin Wang. This is an open access article distributed under the Creative Commons Attribution License, which permits unrestricted use, distribution, and reproduction in any medium, provided the original work is properly cited.

\begin{abstract}
This paper reports a kind of banana peel carbon (BPC) containing - $\mathrm{OH},-\mathrm{NH}_{2}$ functional groups which prepared through controlling carbonization temperature and its application on the selective adsorption of gold from waste printed circuit boards (PCBs). The adsorption of BPC for $\mathrm{Au}(\mathrm{III})$ reached equilibrium in $30 \mathrm{~min}$ and the adsorption of $\mathrm{Au}(\mathrm{III})$ was favorable at $\mathrm{pH} 2.5$. Meanwhile, the adsorption isotherm showed the maximum adsorption capacity of $801.7 \mathrm{mg} / \mathrm{g}$ for $\mathrm{Au}(\mathrm{III})$. The results displayed that $\mathrm{BPC}$ had a strong selectivity for $\mathrm{Au}(\mathrm{III})$ and a negligible affinity to base metal ions, such as $\mathrm{Cu}(\mathrm{II}), \mathrm{Ni}(\mathrm{II}), \mathrm{Fe}(\mathrm{III})$ and $\mathrm{Pb}(\mathrm{II})$. The BPC adsorbent, which absorbed gold, can be recovered completely by HCl-thiourea solution.
\end{abstract}

Keywords: Banana Peel Carbon; Adsorption; Gold(III); Printed Circuit Boards

\section{Introduction}

The rapidly growing of electronic waste (e-waste), especially the discarded printed circuit boards (PCBs), is creating negative impacts on the environment and also bringing serious problems concerning the waste of metal resources. According to Zhou et al. and Veit et al. [1,2], about $130 \mathrm{~kg}$ copper, $20 \mathrm{~kg}$ tin, $24 \mathrm{~kg}$ lead, $18 \mathrm{~kg}$ nickel, and $0.45 \mathrm{~kg}$ gold are included in each ton of PCBs. What's more, it is important to know that many harmful materials like brominated flame retardant which are highly toxic to the environment are also contained in PCBs. Hence, recycling and reusing the metal resources, especially the precious metals from waste PCBs are important subjects from the points of environment and economy.

As known, precipitation, electrowinning, solvent extraction, carbon and resin adsorption are several common methods for recovery gold from various forms of the lixivium of PCBs [3-9]. Activated carbon (AC), a common adsorbent, was employed to recovery of gold from PCBs due to its relative high-efficiency and lowcost. However, its poor selectivity to some base metal ions

\footnotetext{
${ }^{*}$ Corresponding author.
}

(Cu(II), Ni(II), $\mathrm{Fe}(\mathrm{III}), \mathrm{Pb}(\mathrm{II}))$ and small adsorption capacities for gold ions are fatally defects for $\mathrm{AC}$, which limit its wide application on gold adsorption from PCBs. The poor selectivity of AC was due to the lack of specific functional groups, while for many natural materials, such as banana peel (BP) that is mainly composed of polymers such as lignin, hemicellulose and pectins, not only have developed biological cell structure but also contain rich organic functional groups (-OH, $\left.-\mathrm{NH}_{2},-\mathrm{COOH}\right)$ [10-12]. Some investigations had reported that dried BP could directly extract $\mathrm{Cu}(\mathrm{II}), \mathrm{Cr}(\mathrm{IV}), \mathrm{Cd}(\mathrm{II}), \mathrm{Pb}(\mathrm{II})$ and phenolic compounds from aqueous solution due to their pore structures and functional groups $\left(-\mathrm{OH},-\mathrm{COOH},-\mathrm{NH}_{2}\right)$ on the surface of pores [13-17]. Furthermore, BP extract could be used for the reduction of palladium, gold and silver salts that might attributed to the functional groups and polymers as well as the proteinaceous matter contained in BP [18-20]. BP can also be used for the preparation of porous carbons that own big specific surface area through the etching of chemical activator and carbonization at certain temperature [21].

In this work, we have designed a preparation method of BPC with functional groups $\left(-\mathrm{OH},-\mathrm{NH}_{2}\right)$ through controlling the carbonization temperature of BP. BPC as 
adsorbent, was tested in the adsorption of $\mathrm{Au}(\mathrm{III})$ from gold chloride solution with different concentration, contact time and $\mathrm{pH}$ value. At the same time, gold recovery and adsorbent regeneration were investigated. The selectively recovery of $\mathrm{Au}(\mathrm{III})$ from the lixivium of PCBs was also studied.

\section{Experimental}

\subsection{Materials}

Gold chloride $\left(\mathrm{AuCl}_{3}, \geq 99.9 \%\right)$, hydrochloric acid ( $\mathrm{HCl}$, $36 \%-38 \%$ ), sodium hydroxide ( $\geq 96.0 \%$ ), ammonia liquor $\left(\mathrm{NH}_{3}, 25 \%-28 \%\right)$, ammonium chloride $(\geq 99.5 \%)$, ethylenediamine $\left(\mathrm{C}_{2} \mathrm{H}_{8} \mathrm{~N}_{2}, \geq 99.0 \%\right)$, sodium chlorate $(\geq$ $99.0 \%$ ), sodium chloride $(\geq 99.5 \%)$, thiourea $(\geq 99.0 \%)$, and other chemicals were purchased from Aldrich, China. All chemicals were used as received without further purification. Deionized water was used in all aqueous solution.

Banana peels were obtained from normal ripe yellow bananas (Sesame Banana, Guangdong Province, China) and the waste PCBs were derived from discarded computer motherboard, which were purchased from local supermarket and electronic waste market, respectively.

\subsection{Preparation and Characterization}

\subsubsection{Preparation of BPC}

The detailed procedure for preparing BPC was introduced as follows. Firstly, the BP used for experiment were washed with deionized water thoroughly, and dried in a hot-air oven at $80^{\circ} \mathrm{C}$ for 2 days. After that the brownish dry peels were ground to fine powder using an electrically operated mill, and then passed through 100 mesh sieve $(150 \mu \mathrm{m})$ to obtain experimental BP powder. Finally, the pyrolysis of $\mathrm{BP}$ was performed at $500^{\circ} \mathrm{C}$ for 4 hours under flowing nitrogen at a heating rate of $5^{\circ} \mathrm{C} / \mathrm{min}$ to obtain BPC. The BPC is stirred manually to mix well. There are little difference between batches because the environments of the sources' growing are similar.

\subsubsection{Characterization}

Thermal gravimetric (TG) analysis was carried out using a Netzsch STA449C thermo analysis instrument in the temperature range of $30^{\circ} \mathrm{C}-900^{\circ} \mathrm{C}$ at a heating rate of $10^{\circ} \mathrm{C} / \mathrm{min}$ under nitrogen. The Fourier transform infrared (FTIR) spectra were collected with a Nicolet 670 spectrometer with an attenuated total reflectance (ATR) apparatus. Energy dispersive X-ray analysis (EDX) spectroscopy was performed with a KRATOS AXIS ULTRA (DLD). Nitrogen sorption isotherms of the samples were measured at $77 \mathrm{~K}$ using a Micromeritics ASAP 2020MC analyzer. The specific surface areas were calculated with the Brunauer, Emmett and Teller (BET) method and the pore size distributions were calculated using the Bar-
rett-Joyner-Halenda (BJH) model applied to the desorption branch of the $\mathrm{N}_{2}$ isotherms.

\subsection{Adsorption Performance for Au(III)}

A series of $10 \mathrm{~mL}$ of gold chloride solution were transferred to $50 \mathrm{~mL}$ beaker and about $0.01 \mathrm{~g}$ of adsorbent was added to each vessel. The suspensions were stirred mechanically in a shaker bath at $1-120$ min intervals at room temperature $\left(30^{\circ} \mathrm{C}\right)$ to examine the kinetic reaction. The effect of $\mathrm{pH}$ on the adsorption process was investigated in a range of $1-5$ and small amounts of dilute $\mathrm{HCl}$ and $\mathrm{NaOH}$ solution were added to adjust the $\mathrm{pH}$ value. The adsorbent mass, solution concentration, and volume were the same as described above. The adsorbents and solutions were separated through the common filter device and the suspensions were almost completed separated. After that the concentration of gold ion was determined by atomic absorption spectrometry (AAS, Varian AA220) using an air-acetylene flame and electro thermal atomization with $242.8 \mathrm{~nm}$ as a resonance line as well as the slit width with $1 \mathrm{~nm}$. The adsorption capacity and efficiency of $\mathrm{Au}$ (III) taken up by BPC were determined using aliquots of $10 \mathrm{~mL}$ in a concentration interval, the calculation methods was according to the following equation:

$$
\begin{gathered}
A=\left(C_{0}-C_{e}\right) 100 \% / C_{0} \\
Q_{e}=\left(C_{0}-C_{e}\right) \mathrm{V} / \mathrm{m}
\end{gathered}
$$

where $A(\%)$ is the adsorption efficiency, $Q_{e}(\mathrm{mg} / \mathrm{g})$ is the adsorption capacity, $C_{0}(\mathrm{mg} / \mathrm{L})$ and $C_{e}(\mathrm{mg} / \mathrm{L})$ are the initial and final concentrations of metal ions, respectively. $V(\mathrm{~L})$ is the solution volume and $m(\mathrm{~g})$ is the weight of adsorbent used for experiments.

\subsection{Gold Recovery and Adsorbent Regeneration}

The recovery of adsorbed gold and the regeneration of BPC adsorbent were investigated using $0.7 \mathrm{M}$ thiourea $2 \mathrm{M} \mathrm{HCl}$. The adsorbent $(0.10 \mathrm{~g})$ which adsorbed $\mathrm{Au}(\mathrm{III})$ was washed with deionized water several times and transferred into reagent bottles with lids. After that the desorption agent $(20 \mathrm{~mL})$ was added, and then the mixtures were stirred at room temperature using magnetic stirrer for 4 hours. The content of gold still combined with BPC adsorbent was tested by EDX analysis.

\subsection{Extraction of Au(III) from PCBs}

The sample of the lixivium of PCBs was obtained from laboratory leaching method. The procedure was briefly introduced as follows. First, $50 \mathrm{~g}$ of PCBs powder was added to $500 \mathrm{~mL}$ solution of ammonia water-ammonium 
chloride-ethanediamine (4 M:4 M:1 M) in an opened reactor. The suspensions was stirred mechanically for 5 hours, and at the same time, $100 \mathrm{~mL}$ of $30 \%$ hydrogen peroxide was dropwise added to the aboved mixture in the whole experiment. After that $5.0 \mathrm{~g}$ of sodium chlorate and $75 \mathrm{~mL}$ of hydrochloric acid $(3 \mathrm{M})$ as well as $5.0 \mathrm{~g}$ of PCBs powder already removed copper were mixed at a $250 \mathrm{~mL}$ open reactor using a shaker, allowed to stir 5 hours at room temperature $\left(30^{\circ} \mathrm{C}\right)$. The sample of the lixivium was finally obtained by filtering and its $\mathrm{pH}$ value was adjusted to 2.5 .

$0.05 \mathrm{~g}$ of BPC was added to $50 \mathrm{~mL}$ sample solutions and the mixture were stirred for 3 hours to achieve equilibrium at room temperature. The adsorbents were filtered after adsorbed ions and metal concentrations were analyzed by AAS.

\section{Results and Discussion}

\subsection{Characterization for BPC}

Figure 1 is the thermo gravimetric (TG) curve of raw BP, which was analysised at a heating rate of $10^{\circ} \mathrm{C} / \mathrm{min}$ with a nitrogen flow. As shown in Figure 1, The initial weight loss in the region $50^{\circ} \mathrm{C}-200^{\circ} \mathrm{C}$ was mainly due to moisture and bonding water evaporation adsorbed to the banana peel. The temperature region ranging from $200^{\circ} \mathrm{C}$ $700^{\circ} \mathrm{C}$ was mainly attributed to thermal depolymerization of hemicellulose, cleavage of glycosidic linkages of cellulose and lignin components as well as the decomposition of some biomass, such as proteinaceous matter or ester [22]. After $700^{\circ} \mathrm{C}$, further pyrolyzation of biomass in BP was occured, and almost all the natural organic groups were cracked at this stage. The overview of the elemental analysis of raw BP and BPC at different carbonization temperature are given in Table 1. As listed in Table 1, trogen, potassium, chlorine, silicon and phos-

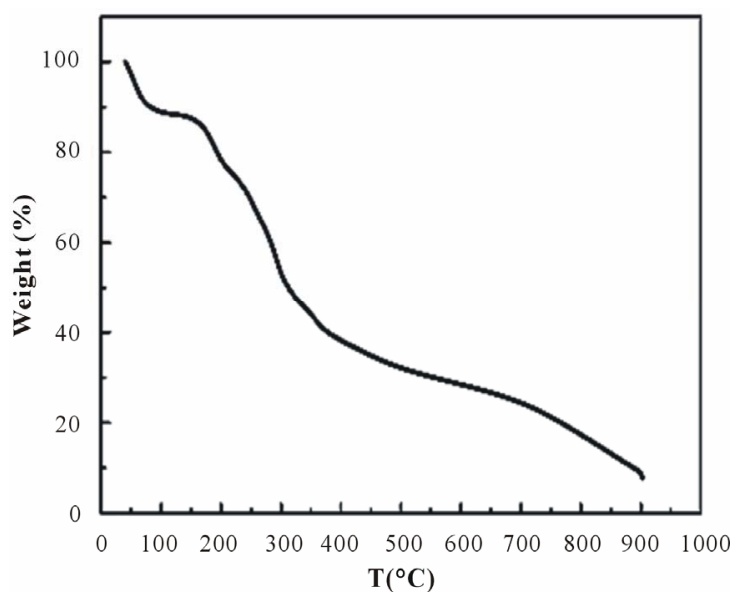

Figure 1. TG curve of raw $B P$. phorus elements. The raw BP contained $59.08 \mathrm{wt} \%$ of carbon, $35.33 \mathrm{wt} \%$ of oxygen, and $0.21 \mathrm{wt} \%$ of nitrogen. The content of nitrogen was gradually decreased from $1.31 \mathrm{wt} \%$ to $0.29 \mathrm{wt} \%$ with the temperature increased from $500^{\circ} \mathrm{C}$ to $700^{\circ} \mathrm{C}$. These dates proved that $200^{\circ} \mathrm{C}$ $700^{\circ} \mathrm{C}$ was the appropriate temperature region for preparing porous carbon materials based on banana peels.

Figure 2 shows the FT-IR spectra of raw banana peel powder and porous carbon materials after carbonization at $300^{\circ} \mathrm{C}, 500^{\circ} \mathrm{C}, 700^{\circ} \mathrm{C}$, respectively. As it can be seen from Figure 2(a), the adsorption bands appearing at $3400,2924,2854,1730$ and $889 \mathrm{~cm}^{-1}$ were assigned to $\mathrm{O}-\mathrm{H}$ stretching of hydroxyl, C-H stretching of alkane, $\mathrm{C}-\mathrm{H}$ and $\mathrm{C}=\mathrm{O}$ stretching of carboxylic acid or ester and $\mathrm{N}-\mathrm{H}$ deformation of amine, respectively [23]. The adsorption peaks appearing at the region of $1600-950 \mathrm{~cm}^{-1}$ were attributed to ester, polysaccharide or protein, which have a strong affinity to both gold metal ion and base metal ions, such as copper, iron, nickel, lead. As seen from (Figure 2(c)), compared with that of raw banana peel (Figure 2(a)), the prominent peak intensity at 3400, $2924,2854,1730$ and $1600-950 \mathrm{~cm}^{-1}$ that attributed to the stretching of $\mathrm{O}-\mathrm{H}, \mathrm{C}-\mathrm{H}$ and $\mathrm{C}=\mathrm{O}$, was significantly reduced, confirming the damage of polysaccharide or protein in porous carbon materials after carbonization at $500^{\circ} \mathrm{C}$. Fortunately, the adsorption bands appearing at $889 \mathrm{~cm}^{-1}$ that attributed to N-H deformation of amines was retained, which would together for the adsorption of $\mathrm{Au}(\mathrm{III})$ with hydroxyl group. From Figures 2(b) and (d), it can be clearly seen that the adsorption peaks at 2924, $2850 \mathrm{~cm}^{-1}$ assigned to $\mathrm{C}-\mathrm{H}$ for porous carbon materials after carbonization at $300^{\circ} \mathrm{C}$ (Figure 2(b)) still existed, while for the materials after treated at $700^{\circ} \mathrm{C}$ (Figure 2(d)), the adsorption peak of $-\mathrm{NH}_{2}$ was disappeared. Therefore, $500^{\circ} \mathrm{C}$ was choosed as the best temperature for carbonization of banana peel.

Figure 3 displays $\mathrm{N}_{2}$ adsorption-desorption isotherms and pore-size distribution of $\mathrm{BP}$ and $\mathrm{BPC}-500^{\circ} \mathrm{C}$. As shown in Figure 3(a), the Type-IV isotherms for BPC$500^{\circ} \mathrm{C}$ with a desorption hysteresis in $\mathrm{P} / \mathrm{P}_{0}$ ranged from 0.6 to 0.8 suggested the existence of developed mesopores. The steep increase in the adsorbed volume at the low relative pressure was related with the presence of micropores, and the almost vertical tails at a relative pressure near to 1.0 revealed the presence of macropores. The BET surface area of BPC $-500^{\circ} \mathrm{C}$ was $6.70 \mathrm{~m}^{2} / \mathrm{g}$ with the total pore volume of $0.018 \mathrm{~cm}^{3} / \mathrm{g}$ as well as the average pore size of $10.17 \mathrm{~nm}$. In contrast, the nitrogen sorption isotherm was an approximately typical Type-I for $\mathrm{BP}$ and the BET surface area was $1.79 \mathrm{~m}^{2} / \mathrm{g}$. The pore size distributions of $\mathrm{BP}$ and $\mathrm{BPC}-500^{\circ} \mathrm{C}$ calculated from the nitrogen desorption branches are given in Figure 3(b). $\mathrm{BPC}-500^{\circ} \mathrm{C}$ displayed typical hierarchical pore size dis- 
Table 1. Element content of BP and BPC at different temperature.

\begin{tabular}{cccccccc}
\hline Temperature ( $\left.{ }^{\circ} \mathbf{C}\right)$ & $\mathbf{C ~ ( \% )}$ & $\mathbf{O}(\mathbf{\%})$ & $\mathbf{N ~ ( \% )}$ & $\mathbf{K ~ ( \% )}$ & $\mathbf{C l}(\mathbf{\%})$ & Si (\%) & P (\%) \\
\hline BP & 59.08 & 35.33 & 0.21 & 4.27 & 0.90 & 0.08 & 0.13 \\
$\mathrm{BPC}-300^{\circ} \mathrm{C}$ & 61.79 & 25.16 & 0.39 & 10.47 & 1.83 & 0.07 & 0.29 \\
$\mathrm{BPC}-500^{\circ} \mathrm{C}$ & 63.79 & 20.59 & 1.31 & 11.06 & 1.94 & 0.87 & 0.44 \\
$\mathrm{BPC}-700^{\circ} \mathrm{C}$ & 46.77 & 27.01 & 0.29 & 20.16 & 3.53 & 1.61 & 0.61 \\
\hline
\end{tabular}

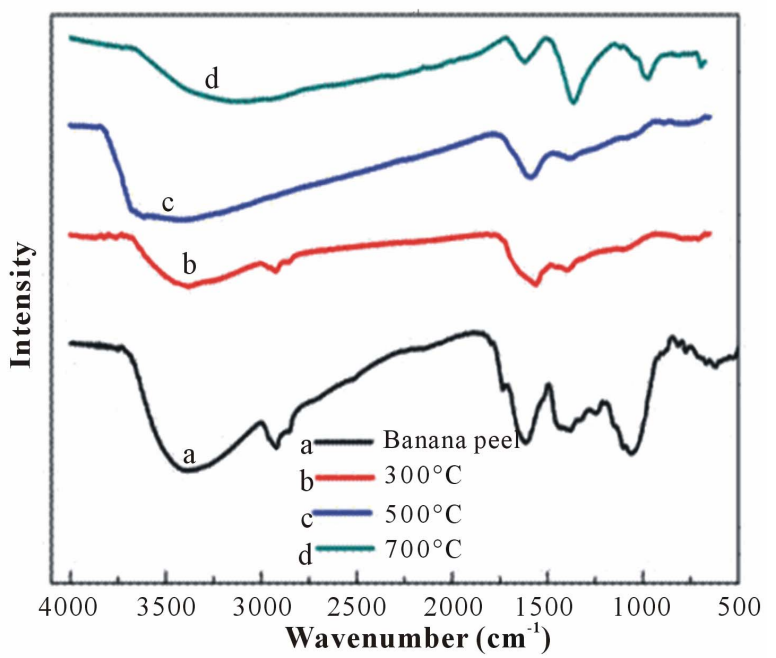

Figure 2. The FT-IR spectra of (a) raw banana peel powder and $(b, c, d)$ porous carbon materials after carbonization at $300^{\circ} \mathrm{C}, 500^{\circ} \mathrm{C}, 700^{\circ} \mathrm{C}$, respectively.

tribution with a highest peak centering at ca. $23.9 \mathrm{~nm}$, as well as several lower peaks centering at ca. 3.5, 10.4, 12.3 and $16.3 \mathrm{~nm}$. It can be clearly observed that the majority of pores of $\mathrm{BPC}-500^{\circ} \mathrm{C}$ were located in the region of mesopores. In comparison, the pore sizes of BP were located in the region of micropores. The detailed physical properties of BP and BPC at different carbon temperatures are tabulated in Table 2.

\subsection{Adsorption Experiments}

The adsorption performance and adsorbent mass as well as the solution concentration of $\mathrm{BPC}-500^{\circ} \mathrm{C}$ adsorption for $\mathrm{Au}(\mathrm{III})$ are summarized in Table 3 . It showed that the adsorption capacity of BPC- $500^{\circ} \mathrm{C}$ gradually increased from 531.36 to $801.70 \mathrm{mg} / \mathrm{g}$ with the increase of gold chloride concentration from 627 to $1354 \mathrm{mg} / \mathrm{L}$, while the adsorption efficiency decreased from $99.99 \%$ to $69.86 \%$. The great adsorption capacity of $\mathrm{BPC}-500^{\circ} \mathrm{C}$ may be attributed to the high affinity of hydroxyl or amino functional groups for $\mathrm{Au}(\mathrm{III})$, however the adsorbed gold ion will be reduced to gold element due to the special chemical structure and crystal defect of carbonaceous material, which creates active site vacancies for further adsorption [24]. Besides, the high specific surface area

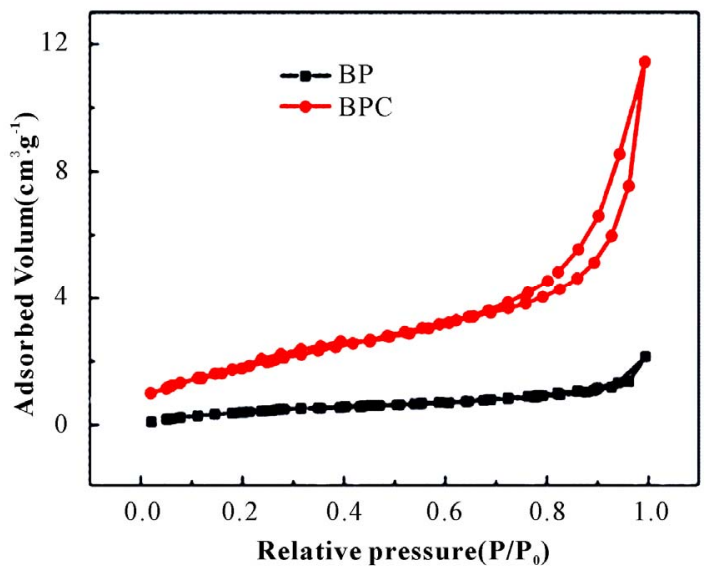

(a)

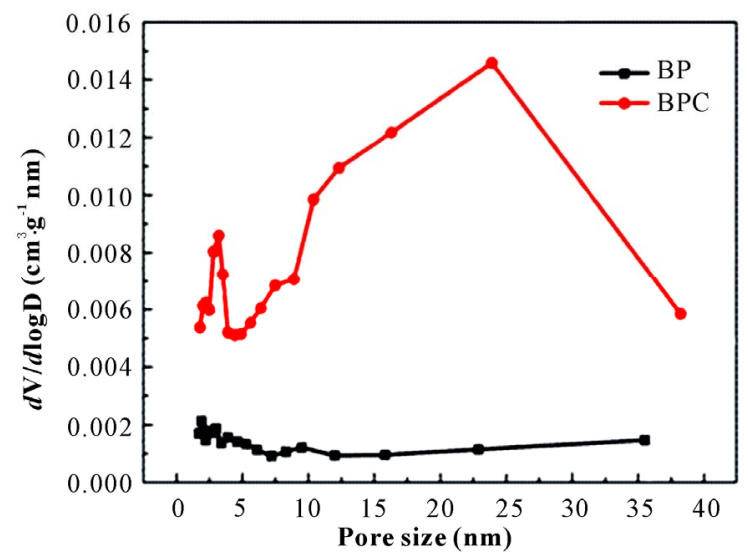

(b)

Figure 3. (a) $N_{2}$ adsorption-desorption isotherms at $77 \mathrm{~K}$ and (b) $\mathrm{BJH}$ pore size distributions for $\mathrm{BP}$ and $\mathrm{BPC}-500^{\circ} \mathrm{C}$.

Table 2. Physical properties of BP and BPC.

\begin{tabular}{ccc}
\hline Samples & SBET $\left(\mathbf{m}^{2} / \mathbf{g}\right)$ & $\mathbf{V t}\left(\mathbf{m}^{3} / \mathbf{g}\right)$ \\
\hline $\mathrm{BP}$ & 1.79 & 0.003 \\
$\mathrm{BPC}-300^{\circ} \mathrm{C}$ & 3.98 & 0.009 \\
$\mathrm{BPC}-500^{\circ} \mathrm{C}$ & 6.97 & 0.018 \\
$\mathrm{BPC}-700^{\circ} \mathrm{C}$ & 7.12 & 0.019 \\
\hline
\end{tabular}

and pore volume of the material might also play a role in gold adsorption process. The adsorption performance of BPC at different carbonization temperatures gave in Table 4 showed an interesting trend between adsorption 
Table 3. Adsorption performance of $\mathrm{BPC}-500^{\circ} \mathrm{C}$ for $\mathrm{Au}(\mathrm{III})$ in different concentrations.

\begin{tabular}{ccccc}
\hline Adsorbent mass (g) & Original solution (mg/L) & Final solution (mg/L) & Adsorption capacity (mg/g) & Adsorption efficiency (\%) \\
\hline 0.0118 & 627 & 0.00 & 531.36 & $>99.99$ \\
0.0118 & 800 & 2.88 & 675.53 & 99.64 \\
0.0117 & 1016 & 170 & 723.08 & 83.27 \\
0.0118 & 1354 & 408 & 801.70 & 69.86 \\
\hline
\end{tabular}

Table 4. Adsorption performance of BP and BPC for Au(III).

\begin{tabular}{ccccc}
\hline Adsorbent & Original solution $(\mathbf{m g} / \mathbf{L})$ & Final solution $(\mathbf{m g} / \mathbf{L})$ & Adsorption capacity (mg/g) & Adsorption efficiency $(\%)$ \\
\hline Banana peel & 1354 & 1120 & 198.31 & 17.28 \\
$\mathrm{BPC}-300^{\circ} \mathrm{C}$ & 1354 & 537 & 692.37 & 60.34 \\
$\mathrm{BPC}-500^{\circ} \mathrm{C}$ & 1354 & 408 & 801.70 & 69.86 \\
$\mathrm{BPC}-700^{\circ} \mathrm{C}$ & 1354 & 1270 & 71.19 & 6.20 \\
\hline
\end{tabular}

capacity and carbonization temperature. It displayed that the adsorption capacity of the adsorbent gradually increased from 198.31 to $801.70 \mathrm{mg} / \mathrm{g}$ with the carbonization temperature increased from $80^{\circ} \mathrm{C}$ to $500^{\circ} \mathrm{C}$, while the adsorption capacity decreased to $71.19 \mathrm{mg} / \mathrm{g}$ with the carbonization temperature increased to $700^{\circ} \mathrm{C}$. The reason is because the reductive group (- $\mathrm{COOH})$ and organic biomass (polysaccharide, protein, ester, etc.) were not completely decomposed at the temperature below $500^{\circ} \mathrm{C}$, while the functional groups $\left(-\mathrm{OH},-\mathrm{NH}_{2}\right)$ responsible for gold adsorption were also decomposed at the temperature over $500^{\circ} \mathrm{C}$. The results indicated that $500^{\circ} \mathrm{C}$ was the best temperature for preparation BPC adsorbent.

Figure 4(a) describes the relationship between $\mathrm{pH}$ and adsorption efficiency of BPC for $\mathrm{Au}(\mathrm{III})$. As shown, $\mathrm{BPC}$ can easily extraction $\mathrm{Au}(\mathrm{III})$ in acidic environment, it owned more than $83.27 \%$ adsorption efficiency in $\mathrm{pH}$ 2.5 and about $48.43 \%, 78.94 \%, 71.46 \%$ in $\mathrm{pH} 1.0,3.5$ and 5.0, respectively. The explanation is that the high concentration of $\mathrm{H}(\mathrm{I})$ species leading to the protonation of main groups $\left(-\mathrm{OH},-\mathrm{NH}_{2}\right)$ responsible for metal extraction, and the surface of the adsorbent is positively charged which made the adsorbent less able to accommodate the adsorption of $\mathrm{Au}(\mathrm{III})$ ions [25]. While at $\mathrm{pH}$ higher than 4.0, the metal solution becomes unstable and gold ion will in the risk of hydrolysis. Thus, $\mathrm{pH} 2-3$ was the best region for BPC adsorbent to adsorb $\mathrm{Au}(\mathrm{III})$, especially $\mathrm{pH} 2.5$ according to experiments. Simultaneously, the effect of contact time on adsorption capacity was plotted in Figure 4(b). As can be seen, the adsorption process was so fast, reaching equilibrium in $30 \mathrm{~min}$.

\subsection{Gold Recovery and Adsorbent Regeneration}

The X-ray photoemission spectra of Au-BPC and (Au $4 f_{5 / 2}, 4 f_{7 / 2}$ ) are given in Figure 5. Figure 5(a) displayed the C 1s, O 1s, O KLL, K 2s, K 2p, Si 2s, Mg 1s, Mg $\mathrm{KLL}, \mathrm{Au} 4 \mathrm{~d}$ and $\mathrm{Au} 4 \mathrm{f}$ core level spectra recorded from the Au-BPC material, indicated that gold was absorbed on the BPC which was in accordance with the EDX pat-

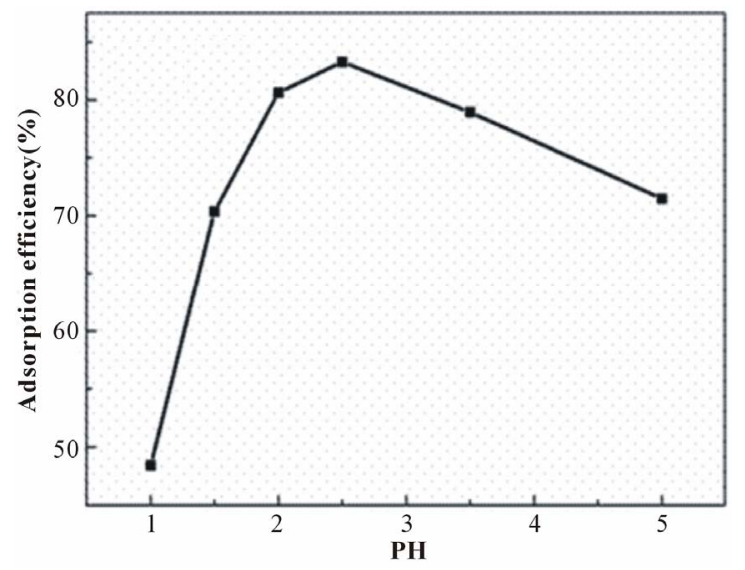

(a)

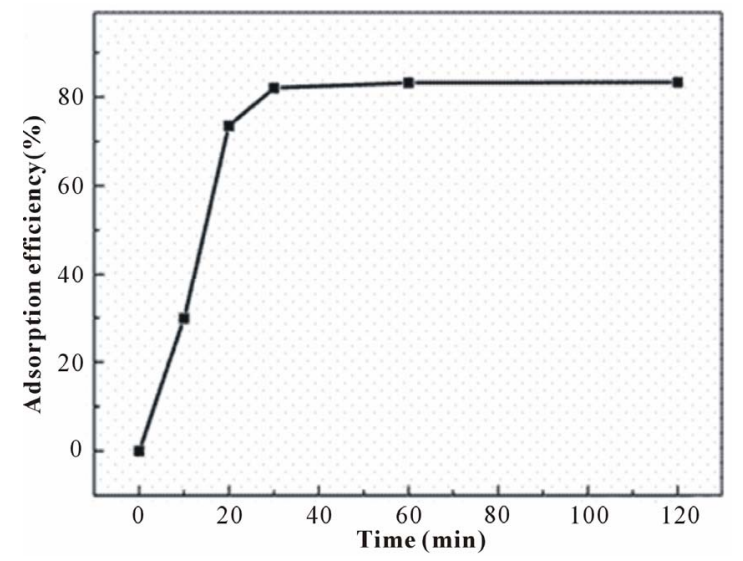

(b)

Figure 4. The effect of (a) $\mathrm{pH}$ and (b) contact time on the extraction of $\mathrm{Au}(\mathrm{III})$. 
terns of Au-BPC Figure 5(a). As shown in Au 4f XPS spectrum Figure 5(b), two peaks located at 84.08 and $87.73 \mathrm{eV}$ (after carbon correction) can be attributed to $\mathrm{Au} 4 \mathrm{f}_{7 / 2}$ and $\mathrm{Au} 4 \mathrm{f}_{5 / 2}$, respectively. This pair of peaks indicated that $\mathrm{Au}$ is present in its elemental state, which suggested that the gold ion had been reduced to element gold on the surface of BPC.

Figure 6 is the EDX patterns of BPC- $500^{\circ} \mathrm{C}$ adsorbent after $\mathrm{Au}(\mathrm{III})$ adsorption and desorption, respectively. Clearly, considerable amount of gold-containing species on the BPC after adsorption Figure 6(a) were removed after $2 \mathrm{M} \mathrm{HCl}-0.7 \mathrm{M}$ thiourea treatment Figure 6(b). As known, the adsorbed gold ion was already reduced to gold and the gold could be resolved in acidic solutions of thiourea in the presence of oxidant according to Murthy [26]. The results indicated that the adsorbent material can be successfully recovered.

\subsection{Extraction of Au(III) from the Lixivium of PCBs}

Figure 7 depicts the selective extraction of $\mathrm{Au}(\mathrm{III})$ on

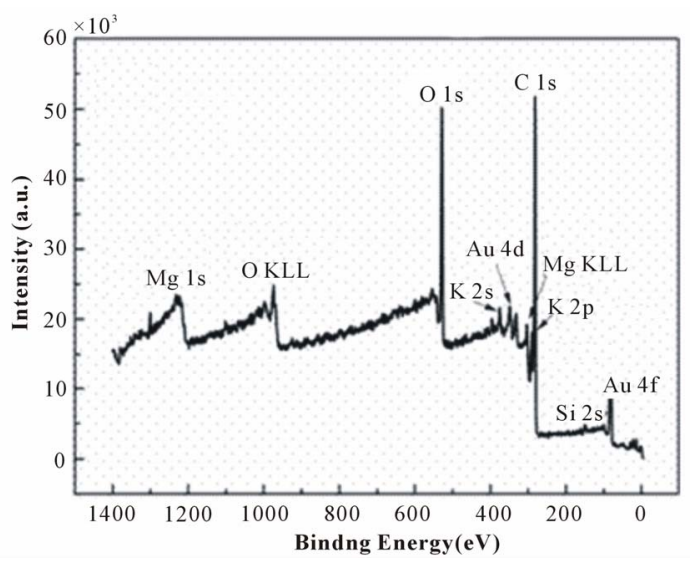

(a)

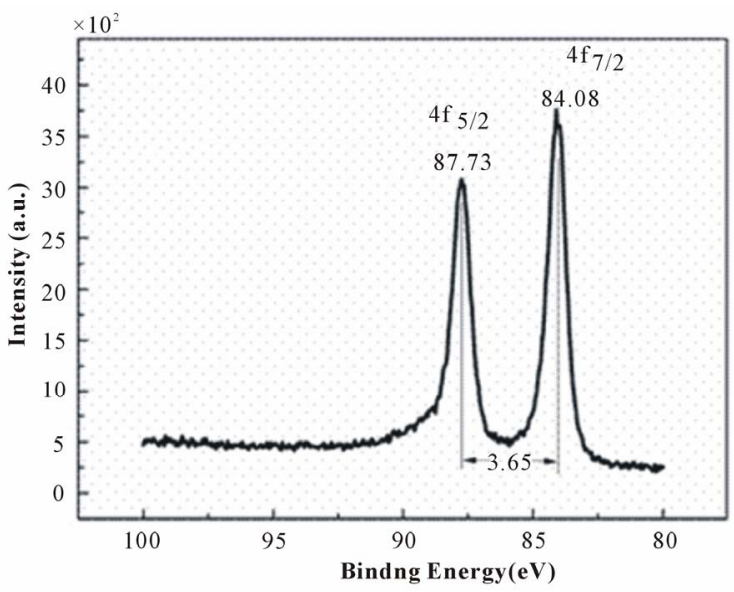

(b)

Figure 5. The XPS spectrum of (a) Au-BPC and (b) Au 4f.

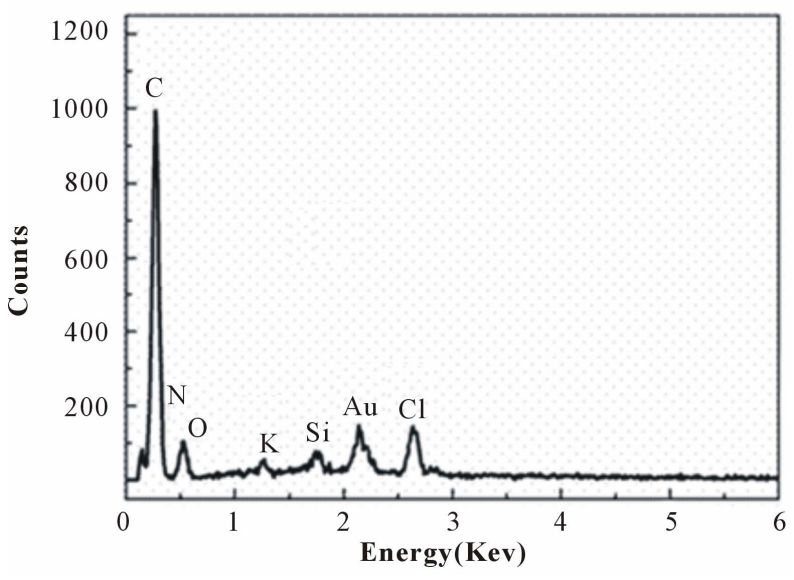

(a)

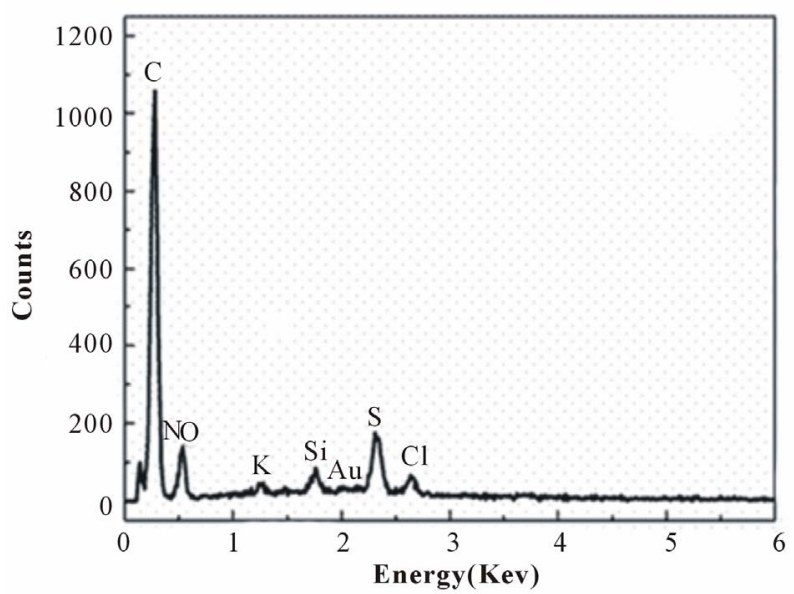

(b)

Figure 6. The EDX patterns of BPC after (a) absorbed and (b) desorbed gold.

BPC from multiple lixivium of PCBs. From Figure 7(a), it can be seen that the concentrations of $\mathrm{Au}(\mathrm{III}), \mathrm{Cu}(\mathrm{II})$, $\mathrm{Ni}(\mathrm{II}), \mathrm{Fe}(\mathrm{III})$ and $\mathrm{Pb}(\mathrm{II})$ in lixivium were $0.54,643,125$, 3.29 and $499 \mathrm{mg} / \mathrm{L}$, and the concentrations became 0.00 , $639,120,2.56$ and $442 \mathrm{mg} / \mathrm{L}$, respectively, after adsorbed by BPC- $500^{\circ} \mathrm{C}$ adsorbent (Figure 7(b)). It was easily known that the adsorption efficiency was $99.99 \%$ of $\mathrm{Au}(\mathrm{III})$, and $0.62 \%$ of $\mathrm{Cu}(\mathrm{II}), 4.00 \%$ of $\mathrm{Ni}(\mathrm{II}), 22.19 \%$ of $\mathrm{Fe}(\mathrm{III})$, and $11.42 \%$ of $\mathrm{Pb}(\mathrm{II})$. This is mainly because of that the reductive group (-COOH) and organic biomass (polysaccharide, protein, ester, etc.) that participate in complex some base metal ions in banana peels were decomposed in the carbonization process, and the functional groups $\left(-\mathrm{OH},-\mathrm{NH}_{2}\right)$ that have a lone pair of electrons could produce coordination compound with $\mathrm{Au}(\mathrm{III})$ that had unpaired and unstable $d$-electrons [27]. The results displayed that $\mathrm{BPC}-500^{\circ} \mathrm{C}$ adsorbent owned strong affinity for $\mathrm{Au}(\mathrm{III})$ and tiny affinity for other base metal ions. 


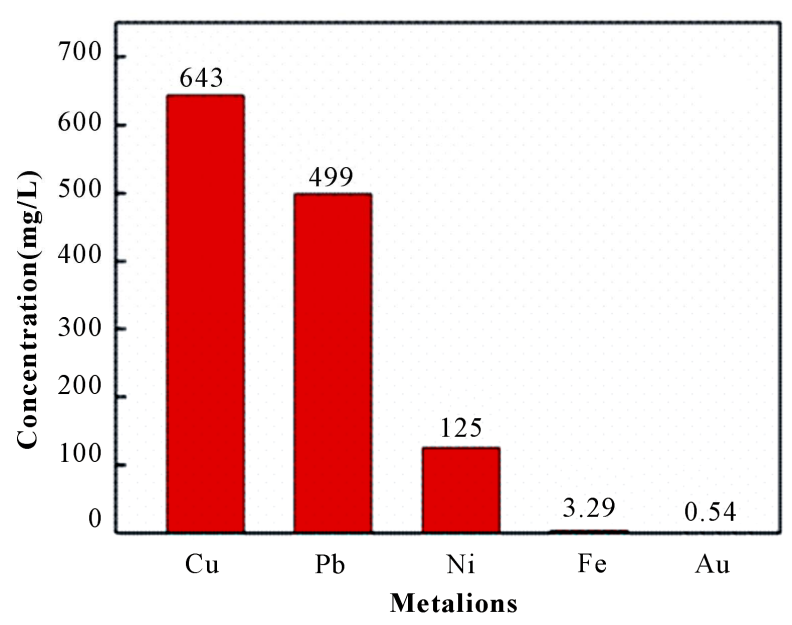

(a)

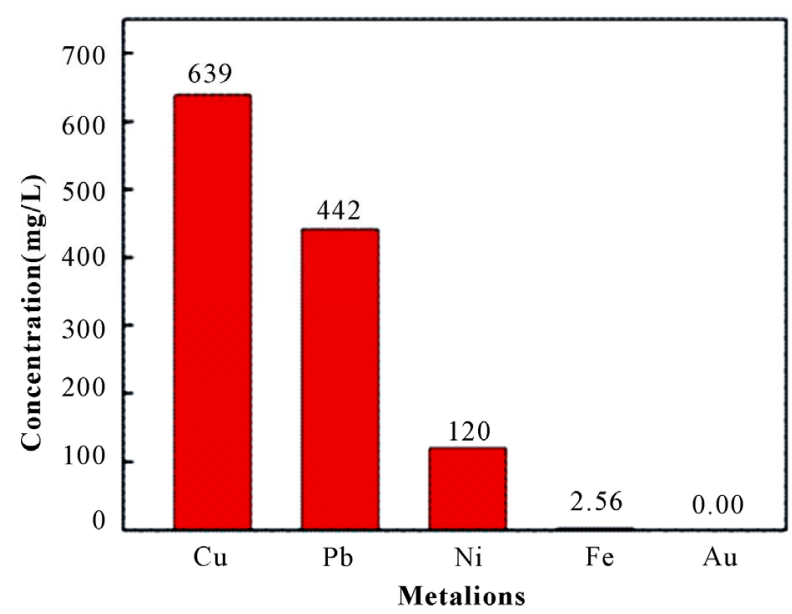

(b)

Figure 7. Compositions of the gold leaching solutions from PCB (a) before and (b) after adsorbed by $B P C-500^{\circ} \mathrm{C}$ adsorbent ( $0.05 \mathrm{~g}$ per $50 \mathrm{~mL}$ solution, $\mathrm{pH} 2.5$ and $\mathrm{T}=303 \pm 2 \mathrm{~K})$.

\section{Conclusion}

BPC that containing functional groups as adsorbent displays an outstanding adsorption performance for $\mathrm{Au}(\mathrm{III})$. This material is very attractive due to its low cost and simple carbonization process. More than that, the high selectivity and adsorption capacity $(801.70 \mathrm{mg} / \mathrm{g})$ for $\mathrm{Au}(\mathrm{III})$ at $\mathrm{pH} 2.5$ are important aspects for recovery high purity gold from PCBs resources. Furthermore, the gold can simply be recovered by stripping with $\mathrm{HCl}$-thiourea agent.

\section{Acknowledgements}

The financial support from Zhejiang major social development of major scientific and technological special projects (NO. 2010C13017) is gratefully acknowledged.

\section{REFERENCES}

[1] G. W. Y. H. Zhou and K. Q. Qiu, "A New Technology for Recycling Materials from Waste Printed Circuit Boards," Journal of Hazardous Materials, Vol. 175, No. 1-3, 2010, pp. 823-828. doi:10.1016/j.jhazmat.2009.10.083

[2] H. M. Veit, A. M. Bernardes, J. Z. Ferreira, J. A. S. Tenorio and C. D. Malfatti, "Recovery of Copper from Printed Circuit Boards Scraps by Mechanical Processing and Electrometallurgy," Journal of Hazardous Materials, Vol. 137, No. 3, 2006, pp. 1704-1709.

doi:10.1016/j.jhazmat.2006.05.010

[3] S. Syed, "Recovery of Gold from Secondary Sources-A Review," Hydrometallurgy, Vol. 115, 2012, pp. 30-51. doi:10.1016/j.jhazmat.2006.05.010

[4] A. C. Grosse, G. W. Dicinoski, M. J. Shaw and P. R. Haddad, "Leaching and Recovery of Gold Using Ammoniacal Thiosulfate Leach Liquors-A Review," Hydrometallurgy, Vol. 69, No. 1-3, 2003, pp. 1-21. doi:10.1016/S0304-386X(02)00169-X

[5] K. Hidetaka, Y. Ri, P. Durga, O. Keisuke, H. Hiroyuki and I. Katsutoshi, "Recovery of Gold from Hydrochloric Acid by Means of Selective Coagulation with Persimmon Extract," Separation Science and Technology, Vol. 43, No. 9-10, 2008, pp. 2375-2385. doi: $10.1080 / 01496390802151716$

[6] J. Y. Park and D. J. Fray, "Recovery of High Purity Precious Metals from Printed Circuit Boards," Journal of Hazardous Materials, Vol. 164, No. 2-3, 2009, pp. 11521158. doi:10.1016/j.jhazmat.2008.09.043

[7] P. Navarroa, C. Vargasa, M. Alonsob and F. J. Alguacil, "Towards a More Environmentally Friendly Process for Gold: Models on Gold Adsorption onto Activated Carbon from Ammoniacal Thiosulfate Solutions," Desalination, Vol. 211, No. 1-3, 2007, pp. 58-63. doi:10.1016/j.desal.2006.03.590

[8] M. I. Jeffrey, D. M. Hewitt, X. Dai and S. D. Brunt, "Ion Exchange Adsorption and Elution for Recovering Gold Thiosulfate from Leach Solutions," Hydrometallurgy, Vol. 100, No. 3-4, 2010, pp. 136-143. doi:10.1016/j.hydromet.2009.11.003

[9] E. Y. Kim, M. S. Kim, J. C. Lee and B. D. Pandey, "Selective Recovery of Gold from Waste Mobile Phone PCBs by Hydrometallurgical Process," Journal of Hazardous Materials, Vol. 198, 2011, pp. 206-215. doi:10.1016/j.jhazmat.2011.10.034

[10] M. Soleimani and T. Kaghazchi, "The Investigation of the Potential of Activated Hard Shell of Apricot Stones as Gold Adsorbents," Journal of Industrial and Engineering Chemistry, Vol. 14, No. 1, 2008, pp. 28-37. doi:10.1016/j.jiec.2007.06.003

[11] D. Parajuli, C. R. Adhikari, H. Kawakita, S. Yamada, K. Ohto and K. Inoue, "Chestnut Pellicle for the Recovery of Gold," Bioresource Technology, Vol. 100, No. 2, 2009, pp. 1000-1002. doi:10.1016/j.biortech.2008.06.058

[12] P. A. M. Teirlinck and F. W. Petersen, "The Nature of Gold-Iodide Adsorption onto Coconut-Shell Carbon," 
Minerals Engineering, Vol. 9, No. 9, 1996, pp. 923-930. doi:10.1016/0892-6875(96)00084-2

[13] R. S. D. Castro, L. Caetano, G. Ferreira, P. M. Padilha, M. J. Saeki, L. F. Zara, M. A. U. Martines and G. R. Castro, "Banana Peel Applied to the Solid Phase Extraction of Copper and Lead from River Water: Preconcentration of Metal Ions with a Fruit Waste," Industrial \& Engineering Chemistry Research, Vol. 50, No. 6, 2011, pp. 3446-3451. doi:10.1021/ie101499e

[14] J. R. Memon, S. Q. Memon, M. I. Bhanger, A. El-Turki, K. R. Hallam and G. C. Allen, "Banana Peel: A Green and Economical Sorbent for the Selective Removal of Cr(VI) from Industrial Wastewater," Colloids Surfaces B: Biointerfaces, Vol. 70, No. 2, 2009, pp. 232-237. doi:10.1016/j.colsurfb.2008.12.032

[15] J. Anwar, U. Shafique, Waheed-uz-Zaman, M. Salman, A. Dar and $\mathrm{S}$. Anwar, "Removal of $\mathrm{Pb}(\mathrm{II})$ and $\mathrm{Cd}(\mathrm{II})$ from Water by Adsorption on Peels of Banana," Bioresource Technology, Vol. 101, No. 6, 2010, pp. 1752-1755. doi:10.1016/j.biortech.2009.10.021

[16] J. Q. Albarelli, R. B. Rabelo, D. T. Santos, M. M. Beppu and M. A. A. Meireles, "Effects of Supercritical Carbon Dioxide on Waste Banana Peels for Heavy Metal Removal," Journal of Supercritical Fluids, Vol. 58, No. 3, 2011, pp. 343-351. doi:10.1016/j.supflu.2011.07.014

[17] M. Achak, A. Hafidi, N. Ouazzani, S. Sayadi and L. Mandi, "Low Cost Biosorbent "Banana Peel" for the Removal of Phenolic Compounds from Olive Mill Wastewater: Kinetic and Equilibrium Studies," Journal of Hazardous Materials, Vol. 166, No. 1, 2009, pp. 117-125. doi:10.1016/j.jhazmat.2008.11.036

[18] A. Bankar, B. Joshi, A. R. Kumar and S. Zinjarde, "Banana Peel Extract Mediated Novel Route for the Synthesis of Silver Nanoparticles," Colloids Surfaces A: Physicochemical and Engineering Aspects, Vol. 368, No. 1-3, 2010, pp. 58-63. doi:10.1016/j.colsurfa.2010.07.024

[19] A. Bankar, B. Joshi, A. R. Kumar and S. Zinjarde, "Banana Peel Extract Mediated Synthesis of Gold Nanoparticles," Colloids Surfaces B: Biointerfaces, Vol. 80, No. 1, 2010, pp. 45-50. doi:10.1016/j.colsurfb.2010.05.029

[20] A. Bankar, B. Joshi, A. R. Kumar and S. Zinjarde, "Banana Peel Extract Mediated Novel Route for the Synthesis of Palladium Nanoparticles," Materials Letters, Vol. 64,
No. 18, 2010, pp. 1951-1953. doi:10.1016/j.matlet.2010.06.021

[21] Y. K. Lv, L. H. Gan, M. X. Liu, W. Xiong, Z. J. Xu, D. Z. Zhu and D. S. Wright, "A Self-Template Synthesis of Hierarchical Porous Carbon Foams Based on Banana Peel for Supercapacitor Electrodes," Journal of Power Sources, Vol. 209, 2012, pp. 152-157. doi:10.1016/i.jpowsour.2012.02.089

[22] B. Deepa, E. Abraham, B. M. Cherian, A. Bismarck, J. J. Blaker, L. A. Pothan, A. L. Leao, S. F. de Souza and M. Kottaisamy, "Structure, Morphology and Thermal Characteristics of Banana Nanofibers Obtained by Steam Explosion," Bioresource Technology, Vol. 102, No. 2, 2011, pp. 1988-1997. doi:10.1016/j.biortech.2010.09.030

[23] J. R. Memon, S. Q. Memon, M. I. Bhanger, G. Z. Memon, A. El-Turki and G.C. Allen, "Characterization of Banana Peel by Scanning Electron Microscopy and FT-IR Spectroscopy and Its Use for Cadmium Removal," Colloids and Surfaces B: Biointerfaces, Vol. 66, No. 2, 2008, pp. 260-265. doi:10.1016/j.colsurfb.2008.07.001

[24] R. Chand, T. Watari, K. Inoue, H. Kawakita, H. N. Luitel, D. Parajuli, T. Torikai and M. Yada, "Selective Adsorption of Precious Metals from Hydrochloric Acid Solutions Using Porous Carbon Prepared from Barley Straw and Rice Husk," Minerals Engineering, Vol. 22, No. 15, 2009, pp. 1277-1282. doi:10.1016/j.mineng.2009.07.007

[25] K. F. Lam, K. L. Yeung and G. McKay, "An Investigation of Gold Adsorption from a Binary Mixture with Selective Mesoporous Silica Adsorbents," Journal of Physical Chemistry B, Vol. 110, No. 5, 2006, pp. 2187-2194. doi:10.1021/jp055577n

[26] D. S. R. Murthy, V. Kumar and K. V. Rao, "Extraction of Gold from an Indian Low-Grade Refractory Gold Ore through Physical Beneficiation and Thiourea Leaching," Hydrometallurgy, Vol. 68, No. 1-3, 2003, pp. 125-130. doi:10.1016/S0304-386X(02)00197-4

[27] H. S. Zou, Z. Q. Chu and G. Lin, "A Novel Recovery Technology of Trace Precious Metals from Waste Water by Combining Agglomeration and Adsorption," Transactions of Nonferrous Metals Society of China, Vol. 17, No. 4, 2007, pp. 858-863. doi:10.1016/S1003-6326(07)60188-5 